\title{
DAMPAK BANK SPECIFIC VARIABLES PADA RASIO NON PERFORMING LOAN DALAM SISTEM PERBANKAN INDONESIA
}

\author{
Anita Carolina \\ Muhammad Madyan \\ a.carolina@student.unair.ac.id \\ Departemen Manajemen Fakultas Ekonomi dan Bisnis Universitas Airlangga
}

\begin{abstract}
Conventional banks are vulnerable to non-performing loans, because the credit is the main source income of a bank. Credit risk may still occur, even though the bank's management has made efforts based credit rating $5 \mathrm{C}$. The purpose of this study was to determine how much influence the variable CAR, LAR, NIM, and ROE against Non-Performing Loans (NPL) in the banking companies listed on BEI. The sampling technique used is purposive sampling with criteria: (1) a conventional commercial bank listed on the BEI 2009-2013 period, (2) the bank that issued the annual financial statements in a row in the period from 2009 to 2013, and (3) bank which has a data completeness NPL, CAR, LAR, NIM, and ROE in the period 2009-2013. Data obtained from the annual report of each bank in 2009-2013. There are a total sample of 29 banks. The analysis technique used is multiple linear regression and hypothesis testing using t-statistic to test the partial regression coefficient and F-statistic to test the effect simultaneously with a significance level of 0.05 . Before being tested by multiple linear regression, first performed classical assumption of normality test data. The results showed that there were no deviations from the classical assumption test. This indicates that the available data is normal or eligible to be used as a multiple linear regression model. From the analysis, CAR and ROE have significant negative effect on the NPL and LAR have not significant negative effect on the NPL, while variable NIM have significant positive effect on the NPL.

Keywords: CAR, LAR, NIM, ROE, NPL, multiple linear regression
\end{abstract}

\section{PENDAHULUAN}

Berdasarkan UU No. 10 Tahun 1998, Bank adalah badan usaha yang menghimpun dana dalam bentuk simpanan dan menyalurkannya kepada masyarakat dalam bentuk kredit dan atau bentuk-bentuk lainnya, dalam rangka meningkatkan taraf hidup masyarakat banyak. Dalam menyalurkan dananya dalam bentuk kredit, bank harus memperhatikan kualitas kreditnya sehingga tidak merugikan bank itu sendiri. Taswan (2010 : 309) menjelaskan bahwa dalam aktivitas perkreditan terdapat unsur waktu, risiko, pendapatan, penyerahan, kepercayaan, persetujuan. Dalam kredit ada petunjuk jarak (waktu) antara penyerahan dengan pelunasan, karena itu selama jangka waktu tersebut terdapat risiko. Namun selain risiko, kredit juga menimbulkan pendapatan. Pendapatan 


\section{Anita Carolina \\ Muhammad Madyan}

kredit dapat berupa bunga atau pendapatan bagi hasil (tergantung sistem bank yang bersangkutan).

Dalam menyalurkan kreditnya, perbankan menghadapi berbagai resiko dibidang kredit, misalnya debitur tidak memenuhi kewajibannya tepat pada waktunya (kelambatan angsuran atau pelunasan) atau lalai membayar pokok pinjaman dan bunga (Suhardjono,2002 : 276). Menurut Fahmi (2011 : 104), Resiko kredit merupakan risiko yang disebabkan oleh ketidakmampuan para debitur dalam memenuhi kewajibannya sebagaimana yang dipersyaratkan oleh pihak kreditur. Resiko kredit umumnya timbul dari berbagai kredit yang masuk dalam kategori bermasalah atau NPL. Non Performing Loan (NPL) merupakan rasio kredit bermasalah terhadap total kredit (Propst, 2012).

Kredit bermasalah yang besar dalam industri perbankan membawa dampak yang luas. Dari sudut pandang mikro hal tersebut merugikan perkembangan usaha dan kesehatan bank, sedangkan dari sudut pandang makro mengingat sebagian dana yang dihimpun bank digunakan untuk menutup kewajiban baik jangka pendek atau panjang, maka kemampuan bank dalam memberikan kredit baru menjadi berkurang sehingga menutup kemungkinan calon debitur baru memperoleh fasilitas kredit bank yang bersangkutan. Dampak lainnya adalah bank akan cenderung terlalu berhati-hati dalam memberikan kredit. Dengan makin selektifnya pemberian kredit, berakibat proses pemberian kredit cenderung lama dari prosedur normal dan ekspansi kredit menjadi turun sehingga mengakibatkan biaya dana dan bunga kredit menjadi lebih tinggi.

Peningkatan dan penurunan NPL pada suatu bank dapat dipengaruhi berbagai faktor. Dalam penelitian ini, faktor-faktor yang diduga mempengaruhi tingkat Non Performing Loan (NPL) adalah Capital Adequacy Ratio (CAR), Loan to Asset Ratio, Net Interest Margin (NIM), dan Return On Equity (ROE).

Capital Adequacy Ratio (CAR) adalah ukuran yang digunakan untuk membantu pemeriksaan kesehatan dan stabilitas sistem perbankan, menunjukkan kapasitas bank untuk mengatasi risiko kredit dan risiko operasional lainnya (Zhou dkk, 2011). Bank dengan CAR baik memiliki profitabilitas yang baik. Penyediaan modal yang baik akan membuat bankbank komersial mampu menyerap kredit yang buruk (Abiola dkk, 2014). Jadi, bank tersebut mampu menutupi resiko kredit yang terjadi dengan besarnya cadangan dana yang diperoleh dari perbandingan modal dan Aktiva Tertimbang Menurut Resiko (ATMR).

Disamping itu, loan to asset ratio merupakan perbandingan seberapa besar kredit yang diberikan bank dibandingkan dengan besarnya total aset yang dimiliki bank. Rasio ini berguna untuk mengukur kemampuan bank dalam memenuhi permintaan kredit para nasabah dengan aktiva yang tersedia (Veithzal, 2007 : 549). Jika bank terlalu cenderung menghindari risiko, maka rasio ini akan cenderung kecil dan sebaliknya, jika bank terlalu ceroboh dalam memberikan kredit maka akan memberikan angka yang besar untuk rasio ini. 


\section{Jurnal Manajemen Teori dan Terapan \\ Tahun 8. No. 3, Desember 2015}

Selain faktor tersebut, rasio Net Interest Margin (NIM) merupakan selisih antara semua penerimaan bunga atas aset bank dan semua biaya bunga atas dana bank yang diperoleh (Darmawi 2011 : 224). Sebuah perubahan kecil dalam NIM memiliki dampak besar pada profitabilitas. NIM yang tinggi berhubungan dengan bank yang menguntungkan (profitable) dengan mempertahankan kualitas aset yang baik (Hui dkk, 2012). Jadi, besarnya NIM akan mempengaruhi laba-rugi bank yang pada akhirnya mempengaruhi kinerja bank tersebut. Semakin besar rasio ini maka akan meningkatkan pendapatan bunga atas aktiva produktif yang dikelola bank.

Return On Equity (ROE) adalah rasio keuangan yang mengacu pada jumlah keuntungan yang diperoleh perbankan dibandingkan dengan jumlah total ekuitas pemegang saham yang diinvestasikan. ROE merupakan imbalan yang diperoleh para pemegang saham untuk investasi mereka. Sebuah perbankan yang memiliki ROE tinggi lebih mampu menghasilkan kas internal. Jadi, semakin tinggi ROE, maka semakin baik sebuah perbankan dalam hal mendapatkan keuntungan (Ongore dkk,2013).

\section{LANDASAN TEORI DAN PENGEMBANGAN HIPOTESIS KREDIT}

Ismail (2010:93) menyatakan bahwa dalam pengertian sederhana kredit merupakan penyaluran dana dari pihak pemilik dana kepada pihak yang memerlukan dana. Penyaluran dana tersebut didasarkan pada kepercayaan yang diberikan oleh pemilik dana kepada pengguna dana. Dalam bahasa latin, kredit berasal dari kata "credere" yang artinya percaya, artinya pihak yang memberikan kredit percaya kepada pihak yang menerima kredit, bahwa kredit yang diberikan pasti akan terbayar. Di lain pihak, penerima kredit mendapat kepercayaan dari pihak yang memberi pinjaman, sehingga pihak peminjam berkewajiban untuk mengembalikan kredit yang telah diterimanya.

Unsur-unsur yang terdapat di dalam kredit adalah sebagai berikut :

1. Kreditor

Kreditor merupakan pihak yang memberikan kredit (pinjaman) kepada pihak lain yang mendapat pinjaman. Pihak tersebut bisa perorangan atau badan usaha.Bank yang memberikan kredit kepada pihak peminjam merupakan kreditor.

2. Debitur

Debitur merupakan pihak yang membutuhkan dana, atau pihak yang mendapat pinjaman dari pihak lain.

3. Kepercayaan (Trust)

Kreditur memberikan kepercayaan kepada pihak yang menerima pinjaman (debitur) bahwa debitur akan memenuhi kewajibannya untuk membayar pinjamannya sesuai dengan jangka waktu tertentu yang diperjanjikan. Bank memberikan pinjaman kepada 


\section{Anita Carolina \\ Muhammad Madyan}

pihak lain, sama artinya dengan bank memberikan kepercayaan kepada pihak peminjam, bahwa pihak peminjam akan dapat memenuhi kewajibannya.

4. Perjanjian

Pejanjian merupakan suatu kesepakatan yang dilakukan antara bank (kreditur) dengan pihak peminjam (debitur).

5. Risiko

Setiap dana yang disalurkan oleh bank selalu mengandung adanya risiko tidak kembalinya dana. Risiko adalah kemungkinan kerugian yang akan timbul atas penyaluran kredit bank.

6. Jangka Waktu

Jangka waktu merupakan lamanya waktu yang diperlukan oleh debitur untuk membayar pinjamannya kepada kreditur.

7. Balas Jasa

Setiap imbalan atas dana yang disalurkan oleh kreditur, maka debitur akan membayar sejumlah uang tertentu sesuai dengan perjanjian. Dalam perbankan konvensional, imbalan tersebut berupa bunga.

Kredit bank menurut kualitasnya didasarkan atas risiko kemungkinan menurut bank terhadap kondisi dan kepatuan debitur dalam memenuhi kewajiban untuk membayar bunga, mengangsur, serta melunasi pinjamannya kepada bank.Jadi, unsur utama dalam menentukan kualitas tersebut adalah waktu pembayaran bunga, pembayaran angsuran, maupun pelunasan pokok pinjaman. Perinciannya adalah sebagai berikut :

1. Kredit Lancar (Pass)

Kredit digolongkan lancar apabila memenuhi kriteria seperti di bawah ini :

a. Pembayaran angsuran pokok dan/ atau bunga tepat waktu; dan

b. Memiliki mutasi rekening yang aktif; atau

c. Bagian dari kredit yang dijamin dengan agunan tunai (cash collateral).

2. Perhatian Khusus (Special Mention)

Kredit digolongkan ke dalam kredit perhatian khusus apabila memenuhi kriteria :

a. Terdapat tunggakan angsuran pokok dan/ atau bunga yang melampaui 90 hari; atau

b. Kadang-kadang terjadi cerukan; atau

c. Mutasi rekening relatif aktif; atau

d. Jarang terjadi pelanggaran terhadap kontrak yang diperjanjikan; atau

e. Didukung oleh pinjaman baru.

3. Kurang Lancar (Substandard)

Kredit yang digolongkan ke dalam kredit kurang lancar apabila memenuhi kriteria :

a. Terdapat tunggakan angsuran pokok dan/ atau bunga yang telah melampaui 90 hari; atau

b. Sering terjadi cerukan; atau

c. Frekuensi mutasi rekening relatif rendah; atau

d. Terjadi pelanggaran terhadap kontrak yang diperjanjikan lebih dari 90 hari; atau 
e. Terdapat indikasi masalah keuangan yang dihadapi debitur; atau

f. Dokumentasi pinjaman yang lemah.

4. Diragukan (Doubtful)

Kredit yang digolongkan ke dalam kredit diragukan apabila memenuhi kriteria:

a. Terdapat tunggakan angsuran pokok dan/ atau bunga yang telah melampaui 180 hari; atau

b. Terjadi cerukan yang bersifat permanen; atau

c. Terjadi wanprestasi lebih dari 180 hari; atau

d. Terjadi kapitalisasi bunga; atau

e. Dokumentasi hukum yang lemah baik untuk perjanjian kredit maupun pengikatan jaminan.

5. Macet (Loss)

Kredit digolongkan ke dalam kredit macet apabila memenuhi kriteria :

a. Terdapat tunggakan angsuran pokok dan/ atau bunga yang telah melampaui 270 hari; atau

b. Kerugian operasional ditutup dengan pinjaman baru; atau

c. Dari segi hukum maupun kondisi pasar, jaminan tidak dapat dicairkan pada nilai wajar.

\section{Non Performing Loans (NPL)}

NPL merupakan kredit dengan kualitas Kurang Lancar, Diragukan, dan Macet (Charles dkk,2013). Stephen (2002:445) menjelaskan bahwa suatu pinjaman dapat diklasifikasikan sebagai "bermasalah" atau "normal" setelah semua pembayaran yang jatuh tempo telah dibuat dan pembayaran telah diterima sesuai jadwal untuk jangka waktu tertentu. Definisi yang paling umum dari non performing loan adalah dimana peminjam terlambat dalam melakukan pembayaran lebih dari hari yang ditetapkan dalam pembayaran pinjaman yang dijadwalkan.

Untuk mengetahui besarnya tingkat NPL suatu bank, maka diperlukan suatu ukuran. Bank Indonesia menginstruksikan perhitungan NPL dalam laporan tahunan perbankan nasional sesuai dengan Surat Edaran Bank Indonesia No. 3/33/DPNP tanggal 14 Desember 2001 tentang perhitungan rasio keuangan bank, yang dirumuskan sebagai berikut :

$\mathrm{NPL}=\frac{\text { Jumlah kredit kurang lancar,diragukan,dan macet }}{\text { Total Kredit }} \times 100 \%$

Agar dapat menentukan tingkat yang wajar atau sehat dilihat dari keberadaan NPL diperlukan suatu standar ukuran yang tepat. Bank Indonesia menetapkan bahwa tingkat NPL yang wajar berkisar antara 3\%-5\% dari total portofolio kreditnya.

\section{Variabel spesifik bank yang mempengaruhi rasio Non Performing Loan : Capital Adequacy Ratio (CAR)}

Darmawi (2011:97) juga menjelaskan bahwa CAR merupakan perbandingan antara modal dengan Aktiva Tertimbang Menurut Risiko (ATMR). Capital Adequacy Ratio (CAR) merupakan rasio yang bertujuan untuk memastikan bahwa bank dapat menyerap kerugian 


\section{Anita Carolina \\ Muhammad Madyan}

yang timbul dari aktivitas yang dilakukan. Basel II mempersyaratkan bahwa bank harus menyediakan modal sebesar $8 \%$ terhadap aset tertimbang menurut risiko (Basel accord).

Rasio ini dihitung dengan rumus sebagai berikut :

CAR $=\frac{\text { Modal Bank }}{\text { Aktiva Tertimbang Menurut Risiko }} \times 100 \%$

CAR yang baik menandakan bahwa bank memiliki kemampuan yang baik untuk tetap bertahan dari loan yang bergejolak. Rivai (2007:548) juga menjelaskan bahwa CAR digunakan untuk mengukur kemampuan dana intern untuk menutup kredit macet. Semakin besar rasio ini, maka semakin baik performa perkreditan bank tersebut karena semakin besar dana yang tersedia untuk menutup kredit macet.

$\mathrm{H}_{1}$ : Capital adequacy ratio berpengaruh negatif terhadap non performing loan.

\section{Loan to Asset Ratio (LAR)}

Kasmir (2000 : 270) juga menjelaskan bahwa loan to asset ratio merupakan rasio untuk mengukur jumlah kredit yang disalurkan dengan jumlah harta yang dimiliki bank. Semakin tinggi rasio ini, tingkat likuiditasnya semakin kecil karena jumlah aset yang diperlukan untuk membiayai kreditnya menjadi semakin besar. Rasio ini dirumuskan sebagai berikut :

Loan to Asset Ratio $=\frac{\text { Jumlah Kredit yang Diberikan }}{\text { Jumlah Asset }} \times 100 \%$

Khemraj dkk (2009) dalam penelitiannya juga menemukan pengaruh yang positif loan to asset ratio terhadap NPL. Hal ini memberi makna apabila pertumbuhan kredit berkurang, loan to asset ratio juga berkurang. Klein (2013) menjelaskan bahwa pinjaman berlebihan yang diukur dengan loan to aset rasio, menyebabkan NPL lebih tinggi. Berdasarkan, penelitian-penelitian tersebut, maka loan to asset ratio memiliki pengaruh yang positif terhadap NPL.

$\mathrm{H}_{2}$ : Loan to asset ratio berpengaruh positif terhadap non performing loan

\section{Net Interest Margin (NIM)}

Rasio ini menunjukkan kemampuan earning assets dalam menghasilkan pendapatan bunga bersih. Pendapatan bunga bersih diperoleh dengan melihat laporan laba rugi pos pendapatan (beban) bunga bersih (Rivai, Basir, Sudarto 2013: 481). NIM berfokus pada keuntungan yang diperoleh pada pinjaman, investasi dan kegiatan pendanaan (Ameur dkk,2013). Rasio ini dirumuskan sebagai berikut :

NIM $=\frac{\text { Pendapatan Bunga Bersih }}{\text { Aktiva } \text { Produktif }} X 100 \%$

Pendapatan bunga bersih yang tinggi ini merupakan akibat dari lebarnya spread pendapatan bunga dengan beban bunga bank tersebut. Spread yang lebar ini dikarenakan suku bunga kredit yang terlalu tinggi jika dibandingkan dengan suku bunga dana, sehingga pendapatan bunga bersih sebuah bank meningkat. Kondisi seperti ini menguntungkan bagi pihak bank, tetapi bisa merugikan bagi para debitur karena harus membayar bunga kredit cukup tinggi. Hal ini dapat memicu peningkatan NPL. 
$\mathrm{H}_{3}$ : Net interest margin berpengaruh positif terhadap non performing loan

\section{Return On Equity (ROE)}

Dendawijaya (2005:120) menjelaskan bahwa ROE adalah perbandingan antara laba bersih bank dengan modal sendiri. Rasio ini dapat dirumuskan sebagai berikut :

$\mathrm{ROE}=\frac{\text { Laba Bersih }}{\text { Modal sendiri }} \times 100 \%$

Ali (2013) menemukan pengaruh negatif ROE terhadap NPL, dimana kenaikan ROE menunjukkan pengurangan NPL, begitu pula sebaliknya. Penemuan ini juga didukung oleh Makri dkk (2014) yang menjelaskan bahwa kemerosotan rasio profitabilitas seperti ROE membawa kepada peningkatan pada non performing loan. Hal ini terkait dengan perilaku pengambilan resiko, dimana bank dengan manajemen yang buruk akan mengarah pada aktivitas berisiko dan kinerjanya akan semakin menurun sehingga dapat meningkatkan NPL.

$\mathrm{H}_{4}$ : Return on equity berpengaruh negatif terhadap non performing loan

\section{METODE PENELITIAN}

\section{Pendekatan Penelitian}

Berdasarkan variabel-variabel yang telah diteliti dan model penelitian yang telah disusun, maka penelitian ini menggunakan penelitian kuantitatif untuk menjawab rumusan masalah. Pendekatan kuantitatif menitik beratkan pada pengujian hipotesis, mengukur variabel yang sedang diteliti dan akan menghasilkan kesimpulan yang dapat digeneralisasikan. Pendekatan kuantitatif ini menggunakan analisis metode regresi linier berganda.

Metode yang digunakan dalam penentuan sampel adalah purposive sampling, dengan kriteria-kriteria sebagai berikut:

1. Subjek penelitian merupakan bank yang terdaftar di Bursa Efek Indonesia selama periode 2009- 2013.

2. Bank yang menerbitkan laporan keuangan tahunan secara berturut- turut dalam periode tahun 2009-2013.

3. Bank yang memiliki kelengkapan data NPL, CAR, LAR, NIM, dan ROE dalam periode tahun 2009-2013.

\section{Kerangka Pemikiran}

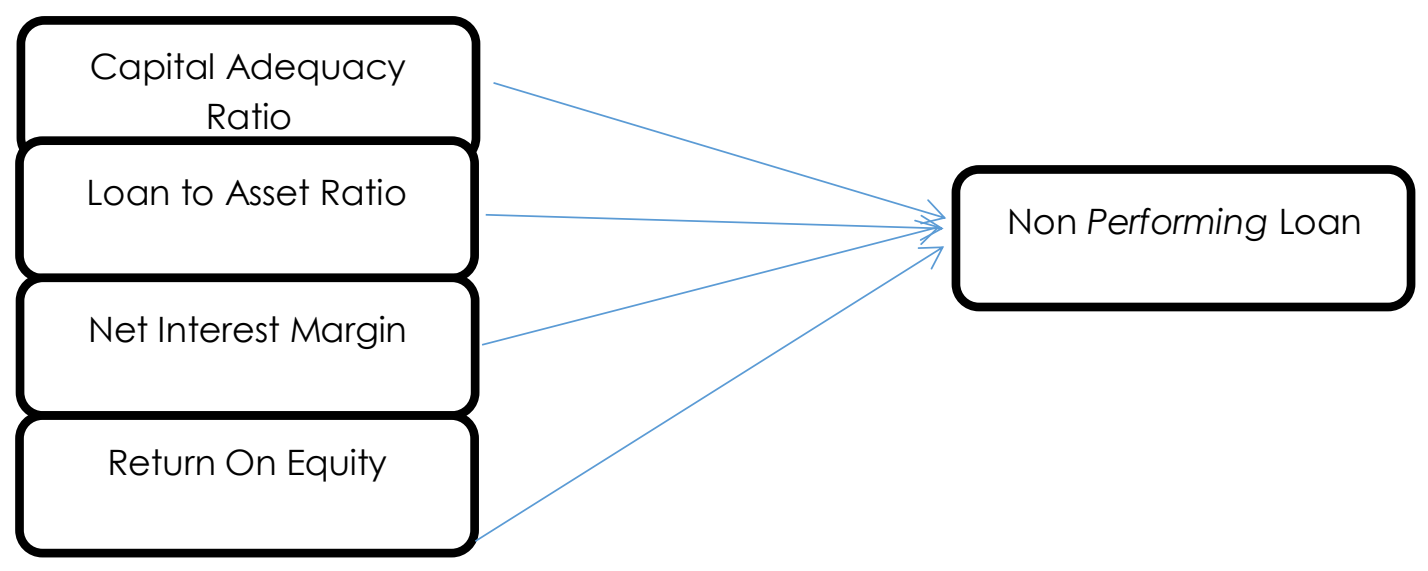




\section{Anita Carolina \\ Muhammad Madyan}

\section{Definisi Operasional Variabel}

Adapun variabel yang digunakan dalam penelitian ini beserta definisi operasionalnya, yaitu:

1. Non Performing Loan (NPL) adalah perbandingan antara jumlah kredit dalam kualitas kurang lancar, diragukan dan macet dengan total kredit.

Rumus : NPL = Jumlah non performing loan / total kredit $\times 100 \%$

2. Capital Adequacy Ratio (CAR) merupakan perbandingan antara jumlah modal dengan aktiva tertimbang menurut risiko (ATMR).

Rumus : CAR $=$ Modal $/$ ATMR $\times 100 \%$

3. Loan to Asset Ratio adalah rasio yang digunakan untuk mengukur tingkat likuiditas bank yang menunjukkan kemampuan bank untuk memenuhi permintaan kredit dengan menggunakan total aset yang dimiliki bank.

Rumus : LAR = Jumlah kredit yang diberikan / jumlah aset $\times 100 \%$

4. Net Interest Margin (NIM) merupakan rasio yang menunjukkan kemampuan earning assets dalam menghasilkan pendapatan bunga bersih.

Rumus : NIM = Pendapatan bunga bersih / aktiva produktif $\times 100 \%$

5. Return On Equity (ROE) adalah perbandingan antara laba bersih bank dengan modal sendiri.

Rumus : ROE : Laba bersih / Modal sendiri x 100\%

\section{Model Analisis Data}

Untuk menguji pengaruh capital adequacy ratio, loan to asset ratio, net interest margin dan return on equity terhadap non performing loan digunakan model regresi berganda seperti berikut :

$N P L_{(i, t)}=a+\beta_{1} C A R_{i, t}+\beta_{2} L A R_{i, t}+\beta_{3} N I M_{i, t}+\beta_{4} R O E_{i, t}+e$

Keterangan:

NPL $($ i, $\quad$ : NPL perbankan i pada tahun $\dagger$

a : : konstanta dari persamaan regresi

$\beta_{1}, \beta_{2}, \beta_{3}, \beta_{4} \quad$ : koefisien regresi

CAR $\quad$ : variabel capital adequacy ratio perbankan i pada tahun $\dagger$

$L_{A R} \quad$ : variabel loan to asset ratio perbankan i pada tahun $\dagger$

NIMi, $\quad$ : variabel net interest margin perbankan i pada tahun $\dagger$

$\mathrm{ROE}_{\mathrm{i}, \mathrm{t}} \quad$ : variabel return on equity perbankan i pada tahun $\dagger$

e $\quad$ : error atau kesalahan prediksi 


\section{HASIL DAN PEMBAHASAN}

\begin{tabular}{|l|l|l|l|l|l|}
\hline Variabel & $\mathbf{N}$ & $\begin{array}{l}\text { Minimum } \\
\mathbf{( \% )}\end{array}$ & $\begin{array}{l}\text { Maksimum } \\
\mathbf{( \% )}\end{array}$ & Rata-Rata & $\begin{array}{l}\text { Standar } \\
\text { Deviasi }\end{array}$ \\
\hline Non Performing Loan & 145 & 0,14 & 50,96 & 3,3225 & 5,62353 \\
\hline Capital Adequacy Ratio & 145 & 8,02 & 46,79 & 16,6643 & 5,78427 \\
\hline Loan to Asset Ratio & 145 & 30,93 & 80,09 & 63,4036 & 10,27133 \\
\hline Net Interest Margin & 145 & 0,76 & 16,64 & 5,8319 & 2,53017 \\
\hline Return On Equity & 145 & $-167,53$ & 402,86 & 15,1804 & 40,63913 \\
\hline
\end{tabular}

\begin{tabular}{|c|c|c|c|c|c|c|}
\hline $\begin{array}{l}\text { Variabel } \\
\text { Dependen }\end{array}$ & $\begin{array}{l}\text { Variabel } \\
\text { Independen }\end{array}$ & $\begin{array}{l}\text { Koefisien } \\
\text { Regresi }\end{array}$ & $\begin{array}{l}\text { Std. } \\
\text { Error }\end{array}$ & $\begin{array}{l}t \quad- \\
\text { hitung }\end{array}$ & $\begin{array}{l}\text { Sig. } \\
t / 2\end{array}$ & Kesimpulan \\
\hline \multirow{5}{*}{ NPL } & (Constant) & 5,662 & 1,042 & 5,435 & 0,000 & \\
\hline & CAR & $-0,111$ & 0,025 & $-4,540$ & 0,000 & Ho ditolak \\
\hline & LAR & $-0,020$ & 0,014 & $-1,490$ & 0,0695 & $\mathrm{H}_{0}$ diterima \\
\hline & NIM & 0,149 & 0,059 & 2,543 & 0,006 & $\mathrm{H}_{0}$ ditolak \\
\hline & ROE & $-0,067$ & 0,007 & $-9,096$ & 0,000 & $\mathrm{H}_{0}$ ditolak \\
\hline \multicolumn{2}{|c|}{ R Square (R2) } & \multicolumn{5}{|l|}{0,421} \\
\hline \multicolumn{2}{|c|}{ Durbin Watson } & \multicolumn{5}{|l|}{1,768} \\
\hline \multicolumn{2}{|l|}{ F hitung } & \multicolumn{5}{|l|}{24,573} \\
\hline \multicolumn{2}{|c|}{ Probabilitas F (sig) } & \multicolumn{5}{|l|}{.000} \\
\hline
\end{tabular}

Dari hasil pengujian di atas maka dapat disusun suatu persamaan regresi linear berganda sebagai berikut:

$N P L=5,662-0,111$ CAR -0,020 LAR +0,149 NIM -0,067 ROE

Keterangan :

1. Konstanta $\lambda$ sebesar 5,662 menunjukkan jika variabel independen bernilai nol, maka tingkat NPL naik senilai 5,662 .

2. Koefisien regresi $\left(\beta_{1}\right)$ untuk CAR sebesar $-0,111$ yang menunjukkan jika CAR dan NPL memiliki hubungan negatif, apabila terjadi peningkatan satu satuan CAR maka menurunkan NPL 0,111 . 


\section{Anita Carolina \\ Muhammad Madyan}

3. Koefisien regresi $\left(\beta_{2}\right)$ untuk LAR sebesar $-0,020$ yang menunjukkan jika LAR dan NPL memiliki hubungan negatif, apabila terjadi peningkatan satu satuan nilai LAR maka menurunkan NPL $-0,020$.

4. Koefisien regresi $\left(\beta_{3}\right)$ untuk NIM sebesar 0,149 yang menunjukkan jika NIM dan NPL memiliki hubungan positif, apabila terjadi peningkatan satu satuan NIM maka meningkatkan NPL 0,149 .

5. Koefisien regresi $\left(\beta_{4}\right)$ untuk ROE sebesar $-0,067$ yang menunjukkan jika ROE dan NPL memiliki hubungan negative, apabila terjadi peningkatan satu satuan nilai ROE maka menurunkan NPL sebesar 0,067.

\section{Pengaruh CAR terhadap NPL}

CAR merupakan perbandingan antara modal dengan Aktiva Tertimbang Menurut Risiko (ATMR). CAR merupakan rasio yang bertujuan untuk memastikan bahwa bank dapat menyerap kerugian yang timbul dari aktivitas yang dilakukan, dimana salah satunya adalah resiko kredit. Semakin tinggi CAR mengindikasikan bahwa bank mempunyai modal yang cukup baik dalam menunjang kebutuhannya serta mampu mengontrol resiko yang timbul.

Berdasarkan hasil penelitian ini diketahui bahwa CAR berpengaruh negatif signifikan terhadap NPL bank. Menurut penelitian Fauzy (2010), semakin besar tingkat kecukupan permodalan bank, maka semakin besar kemampuan bank untuk mencadangkan kredit macet sehingga resiko kredit juga menurun. Hal ini menyebabkan kemungkinan bank untuk dapat bertahan dari masalah loans tersebut semakin baik, sehingga membuat tingkat NPL semakin kecil. Sehubungan dengan hal tersebut, semakin besar kecukupan permodalan bank, maka bank tersebut bisa dikatakan dalam kondisi yang sehat.

Sinkey dan Greenawalt (1991) menyatakan bahwa bank yang memiliki CAR yang cukup akan memiliki tingkat NPL yang rendah. Oleh karena itu, CAR berpengaruh negatif signifikan terhadap NPL. Penelitian ini sejalan dengan penelitian yang dilakukan oleh Ali (2013) dan Boudriga (2009) bahwa CAR berpengaruh negatif terhadap NPL.

\section{Pengaruh LAR terhadap NPL}

Loan to Asset Ratio (LAR) menunjukkan seberapa besar kredit yang diberikan bank dibandingkan dengan besarnya total aset yang dimiliki bank. Rasio ini berguna untuk mengukur kemampuan bank dalam memenuhi permintaan kredit para nasabah dengan aktiva yang tersedia. Semakin besar kredit yang diberikan oleh bank, maka semakin besar presentase rasio ini dan semakin besar pula resiko kredit yang akan dihadapi oleh bank tersebut.

Berdasarkan hasil penelitian ini diketahui bahwa LAR cenderung memiliki pengaruh negatif tidak signifikan terhadap NPL bank. Hal ini disebabkan banyak bank dalam penelitian ini memiliki LAR yang besar, namun NPL nya kecil. Ini menunjukkan bahwa bank dengan LAR yang tinggi memiliki analisa kredit yang baik sehingga mampu memberikan kredit kepada debitur yang tepat. Dengan demikian, resiko gagal bayar dapat 


\section{Jurnal Manajemen Teori dan Terapan \\ Tahun 8. No. 3, Desember 2015}

diminimalkan karena debitur mampu mengembalikan kredit yang telah diberikan oleh pihak bank. Kondisi seperti ini menunjukkan walaupun bank memberikan kredit dalam jumlah yang besar, tetapi tingkat NPLnya masih dalam batas yang wajar.

Hasil penelitian ini berbeda dengan penelitian yang dilakukan Mejra (2009) yang menemukan bahwa loan to asset ratio memberikan kontribusi terhadap peningkatan dinamika rasio NPL, namun didukung oleh penelitian yang dilakukan oleh Ali (2013) yang menjelaskan bahwa loan to asset ratio (LAR) berpengaruh negatif dengan NPL.

\section{Pengaruh NIM terhadap NPL}

NIM mengindikasikan kemampuan bank menghasilkan pendapatan bunga bersih dengan penempatan aktiva produktif. Aktiva produktif yang diperhitungkan adalah aktiva produktif yang dapat menghasilkan pendapatan bunga. Pendapatan bunga bersih adalah pendapatan bunga dikurangi beban bunga. NIM digunakan untuk mengukur kemampuan manajemen bank dalam mengelola aktiva produktifnya untuk menghasilkan pendapatan bunga bersih. Semakin tinggi nilai NIM menunjukkan semakin efektif bank dalam penempatan aktiva produktif dalam bentuk kredit.

Berdasarkan hasil penelitian ini, diketahui bahwa NIM berpengaruh positif signifikan terhadap NPL bank. Dapat diartikan bahwa NIM mempunyai pengaruh terhadap NPL. NIM yang tinggi dari sebuah bank disebabkan oleh tingginya pendapatan bunga bersih yang diterima oleh bank tersebut. Pendapatan bunga bersih yang tinggi ini merupakan akibat dari lebarnya spread pendapatan bunga dengan beban bunga bank tersebut. Spread yang lebar ini dikarenakan suku bunga kredit yang terlalu tinggi jika dibandingkan dengan suku bunga dana, sehingga pendapatan bunga sebuah bank meningkat. Kondisi seperti ini menguntungkan bagi pihak bank, tetapi bisa merugikan bagi para debitur karena harus membayar bunga kredit cukup tinggi. Hal ini dapat memicu peningkatan NPL. Ismail (2009:107) menyatakan bahwa kenaikan suku bunga bisa berdampak pada kenaikan kredit bermasalah.

Ali (2013) dalam penelitiannya menyebutkan bahwa net interest margin memiliki pengaruh yang positif terhadap non performing loan. Penelitian ini berbeda dengan penelitian Ongore akk (2013) yang menyatakan bahwa bahwa NIM memiliki pengaruh negatif dengan NPL.

\section{Pengaruh ROE terhadap NPL}

Nilai ROE mencerminkan seberapa efektif manajemen bank dalam menggunakan dana para pemegang saham, dimana semakin baik ROE maka manajemen semakin efektif dalam memanfaatkan modal pemegang saham. Kenaikan dalam rasio ini berarti terjadi kenaikan laba bersih dari bank yang bersangkutan. Selanjutnya, kenaikan tersebut akan menyebabkan kenaikan harga saham bank yang akan membuat para pemegang saham bank dan para investor di pasar modal ingin membeli saham bank tersebut. 


\section{Anita Carolina \\ Muhammad Madyan}

Berdasarkan penelitian ini diketahui bahwa ROE berpengaruh negatif signifikan terhadap NPL bank. Rasio NPL yang tinggi menunjukkan ROE yang rendah, demikian juga sebaliknya, ROE yang rendah biasanya menunjukkan NPL tinggi (Ali, 2013). ROE yang rendah dari sebuah bank menggambarkan kondisi manajemen bank yang tidak baik. Kondisi seperti ini bisa memicu peningkatan NPL dari sebuah bank, dikarenakan bank tersebut tidak memiliki kemampuan yang baik dalam mengelola kredit yang akan disalurkan.

Park dkk (2012) menyatakan bahwa ketika sebuah bank memiliki ROE yang rendah ditahun ini, bank tersebut akan cenderung melakukan aktivitas berisiko yang dapat meningkatkan NPL nya di tahun yang akan datang. Hal ini terkait dengan perilaku pengambilan resiko, dimana bank yang memiliki ROE rendah akan berusaha meningkatkan pendapatannya ditahun yang akan datang dengan melakukan sejumlah aktivitas yang memiliki resiko. Salah satu aktivitas tersebut adalah dengan memberikan kredit dengan jumlah yang besar, yang tentunya dapat memicu peningkatan NPL. Pemberian kredit yang besar ini tidak diimbangi dengan manajemen yang baik oleh bank tersebut, sehingga justru bisa membawa bank tersebut pada peningkatan rasio NPL.

Oleh karena itu, ROE berpengaruh negatif signifikan terhadap NPL. Hasil penelitian ini bertentangan dengan penelitian Metin dkk (2013) dan Vatansever dan Hepsen ( 2013 ) yang menyatakan bahwa ROE berpengaruh positif signifikan terhadap NPL, namun sesuai dengan penelitian Ali (2013).

\section{DAFTAR REFERENSI}

Ameur, I.G. Ben, Sonia M. Mhiri. 2013. Explanatory Factors of Bank Performance Evidence from Tunisia. International Journal of Economics, Finance and Management. Vol. 2, NO. 1, March 2013.

Boudriga, Abdelkader, Neila B. Taktak, and Sana Jellouli. 2009. Banking Supervision and Nonperforming Loans: A Cross-Country Analysis. Journal of Financial Economic Policy. Vol. 1 No. 4.

Carolina, Anita dan Muhammad Madyan, 2015. Dampak Bank Specific Variables Pada Rasio Non Performing Loan Dalam Sistem Perbankan Indonesia, Program Studi S1 Manajemen Unair, 81.

Darmawi, Herman. 2011. Manajemen Perbankan. Jakarta: Bumi Aksara.

Dendawijaya, Lukman. 2003. Manajemen Perbankan. Jakarta Selatan: Ghalia Indonesia.

Fahmi, Irham. 2011 . Manajemen Risiko Teori, Kasus, dan Solusi. Bandung: Alfabeta.

Festic, Mejra. Financial Stability in the Baltics. Journal of Economics and Finance, 59, 2009, no. 6.

IdowU Abiola. 2014. The Impact of Credit Risk Management on the Commercial Banks Performance in Nigeria. International Journal of Management and Sustainability, 2014, 3(5): 295-306. 


\section{Jurnal Manajemen Teori dan Terapan \\ Tahun 8. No. 3, Desember 2015}

Ismail. 2010. Manajemen Perbankan (Dari Teori Menuju Aplikasi) : Kencana Prenada Media Group

Jha, Suvita and Xiaofeng Hui. 2012. A Comparison of Financial Performance of Commercial Banks: A Case Study of Nepal. African Journal of Business Management. Vol. 6(25), pp. 76017611, 27 June, 2012.

Kasmir.2006. Manajemen Perbankan. Jakarta: PT Raja Grafindo Persada.

Khemraj, Tarron and Sukrishnalall Pasha. 2009. The Determinants of Non-Performing Loans: An Econometric Case Study of Guyana.

Klein, Nir. 2013. Non-Performing Loans in CESEE: Determinants and Impact on Macroeconomic Performance. IMF Working Paper.

Makri, Vasiliki, Athanasios Tsagkanos, and Athanasios Bellas. 2008. Determinants of Non Performing Loans: The Case of Eurozone. PANOECONOMICUS, 2014, 2, pp. 193-206.

Ogboi, Charles. 2013. Impact of Credit Risk Management and Capital Adequacy on the Financial Performance of Commercial Banks in Nigeria. Journal of Emerging Issues in Economics, Finance and Banking. Vol. 2 No.3 September 2013.

Ongore, Vincent Okoth. 2013. Determinants of Financial Performance of Commercial Banks in Kenya. International Journal of Economics and Financial Issues. Vol. 3, No. 1, 2013, pp.237252.

Park, Jung Hyun dan Lei Zhang. 2010. Macroeconomic and Bank-Specific Determinants of the U.S. Non-Performing Loans: Before and During the Recent Crisis.

Propst, Allaina. 2012. Profitability Performance of Banks in the EU: A Cross Country Analysis from 2009-2010. April 26 th 2012.

Rivai, Basir, Sudarto, Veithzal. 2013. Commercial Bank Management: Manajemen Perbankan dari Teori ke Praktik. Jakarta: PT Raja Grafindo Persada.

Shingjergji, Ali. 2013. The Impact of Bank Specific Variables on the Non Performing Loans Ratio in the Albanian Banking System. Research Journal of Finance and Accounting. Vol.4, No.7.

Sinkey, J.F. dan Greenawalt, M.B. 1991. Loan Loss Experience and Risk Taking Behaviour at Large Commercial Banks. Journal of Financial Services Research. Vol.5, No.1.

Stephen. 2002. Commercial Bank Financial Management. New York: Macmillan Publishing Company.

Suhardjono. 2002. Manajemen Perbankan: Teori dan Aplikasi. Yogyakarta: BPFE Yogyakarta. Taswan. 2010. Manajemen Perbankan Konsep, Teknik \& Aplikasi. Yogyakarta: UPP STIM YKPN. Vatansever, Metin and Ali Hepsen. 2013. Determining Impacts on Non-Performing Loan Ratio in Turkey. Journal of Finance and Investment Analysis. Vol. 2, no.4, 2013, 119-129.

Wenqian Zhou. 2011. The Impact of Executive Payment on Firm Performance of the Financial Enterprises in China. Asian Social Science. Vol. 7, No. 8; August 2011. 
Anita Carolina

Muhammad Madyan 